\title{
都市住民の親族ネットワーク
}

\section{Kin Network of Urban Dwellers}

\section{田中 恵 \\ TANAKA Satoshi}

This paper aims to clarify the characteristics of the kin network of urban dwellers by analyzing the factors affecting their formation and some aspects of their intimate networks as indices of selectivity and the preferability in kinship. Data analysis from the survey conducted in seven cities on 732 married residents over thirty years-old found that the educational level and urbanity affect the choice of kin as intimate network partner. It was also revealed that the social context for intimate network is relevant to the size of the network. Other aspects include the frequency of direct contact and how much his or her spouse know his or her intimate network partner.

\section{1.はじめに}

本稿は、都市住民がとり結ぶ親族ネットワークの関係性を、最も親しい人との関係であ るインティメイト・ネットワーク（intimate network）の側面から明らかにすることを目的 としている。

都市を独立変数として、その都市に住む人々の社会的性格や社会関係を明らかにしよう とする考え方は、すでに、ジンメルの著作の中に見られるものである。ジンメルは、『大 都市と心的生活』において、大都市居住者の社会的性格や態度を「小さい町」や「農村」 と対置して特徽づけようとした（Simmel 1903）。このような都市を独立変数とする考え 方の中で、個人がとり結ぶネットワークへの効果に関しては、これまでも、そして、今日 でも、都市社会学の重要な研究テーマの一つになっている。その中で、ウェルマンは、マ クロな社会変動が個人の第一次的関係に及ほす影響に関する議論を、「コミュニティ喪失 論」、「コュニティ存続論」、「コミュニティ解放論」の 3 つに整理した（Wellman 1979）。 「コミュニティ皮失論」は、工業化・官僚制化された都市における親族や近隣の連帯の衰 退を主張する見解であり、「コミュニティ存続論」は、そのような都市にあっても、第一 次的紐帯は繁栄し続けていると主張する見解である。これらに対して、ウェルマンは、コ ミュニティの概念を地理的限定から切り離し、都市の第一次的関係は地域社会を越えて、 空間的に分散したネットワークとして展開するという「コミュニティ解放論」を主張した。 いずれの議論も都市のネットワークへの効果を一定程度、説明するものであり、これらを 援用して検証を試みた研究もある(1)。

さて、親族関係が都市においても存続していることは、「コミュニティ存続論」を主張 する多くの研究で検証されているが、その関係の規模や内容に対する都市度の影響を検証 したのが、フィッシャーである。彼は北カリフォルニアで調査を行い、都市度を「コミュ ニティ内とその近郊に住む人口量」と捉えたうえで（Fischer 1982:23）、semi-rural、 towns、metropolitan、regional coreという 4 つの都市度の異なるコミュニティを比較し、都 
市度の社会的ネットワークへの効果を分析した（Fischer 1982:81）。その中で親族関係に ついては次の知見を得ている。年齢や収入などの影響を取り除いてもなお、都市度は親族 関係に対して、有意な効果をもち、より都市度の高い場所に住む人はより都市度が低い場 所に住む人より親戚の数が少ない。また、都市の人々は農村の人々より、親族関係のかか わり合いにおいて、選択的になる（Fischer 1982:83）。すなわち、親子・きょうだいとい う「中核親族」との関係を中心とする選択的なものになり、他の親戚との関係は衰退する というものである。

この後者の、親族関係の選択性という知見は重要である。日本の都市の親族関係につい ても、すでに、「同族団規定がほぼ消滅しているような状態では、成員資格に関して共有 され得る客観的基準は認め難く、個人の視野構造に基づき、結婚式や葬式あるいは会食や おしゃべりなどの事柄に応じて個人選択的な原理によって関係構成がなされる」と指摘さ れている（大橋・清水 1972）。親族関係は、血縁か姻縁によって結ばれているという事 実と相互認知があって成立するのだが、都市においては、現実のつきあいはそれらだけで は実践されず、個人選択的な原理がさらに働くことによって、親密につきあう親族から関 係が疎遠になる親族までを選別していくのである。都市の親族関係の特性は、制度的・儀 礼的な集団的結びつきから、選択的・非拘束的なネットワークへと変化しているのである

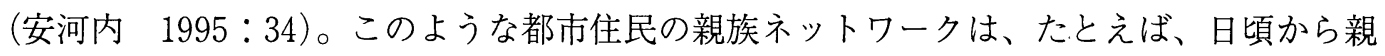
しい親戚の人数などの量的側面、および、領域ごとのサポート機能のあり方、接触の仕方 と頻度、居住地間の時間距離、そして最も親しい人とのつきあい(インティメイト・ネッ トワーク）などの質的側面から捉えていくことが可能である。

インティメイト・ネットワークは、個人がとり結ぶパーソナル・ネットワークの一部で あり、複数、存在する相手のうちのたった 1 人との関係である。しかし、単なる 1 人では ない。個人の選択性・選好性が最も先鋭に表れる特別な関係である。したがって、関係の 選択性を把握する指標の一つとして、インティメイト・ネットワークを明らかにすること は意味のあることだと考えられる。また、インティメイト・ネットワークの分析からは、 「同類結合」を測定することが可能となる。「同類結合」の分析には、「人々の行動面から

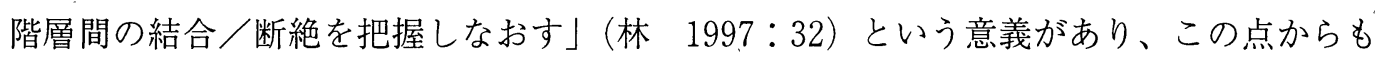
インティメイト・ネットワークを明らかにすることの意味が強調されよう(2)。とはいえ、 インティメイト・ネットワークが示す特性から、パーソナル・ネットワークについて明ら かにできることは、限定的なものであることを留意しておかなくてはならない。

さて、本稿では、先行研究の知見を踏まえて、親族ネットワークの選択性について、そ れが最も先鋭に表出される関係という意味合いから、インティメイト・ネットワークをと りあげ、その規定要因を分析する。次に、インティメイト・ネットワークの特性を「学校 時代の友人」や「職場・仕事関係」など、親戚以外の他の出会いの社会的文脈との比較に よって分析していく。なお、後述するように、本稿で分析するインティメイト・ネットワ ークは、両親・子供・同居している家族以外で最も親しい 1 人との関係である。

以上のような問題意識と分析枠組に基づいて、冒頭に挙げた課題に取り組んでいく。

\section{2. データと変数}

分析に用いるデータは、1995〜1997年に行った「都市度とパーソナルネットワークに関 
する調査」から得られたものである(3)。調査対象は、東京都文京区、同調布市、福岡県福 岡市中央区、同西区、新潟県新潟市、静岡県富士市、島根県松江市に住む20歳から75歳の 男女である。調査法は郵送法で、総抽出標本数 2,100 、有効回収標本数 1,004 、回収率 $47.8 \%$ であったここの中で、本稿の分析で用いるサンプルは、30歳代以上の既婚者（離死 別者を除く）732ケースである。

調査地の人口 (括弧内、人口密度) は、文京区 18 万人 $(16,027.3)$ 、調布市 20 万人 $(9,190.0)$ 、 福岡市中央区 14 万人 $(9,266.2)$ 、同西区 14 万人 $(1,646.8)$ 、新潟市 49 万人 $(2,360.2)$ 、富士 市22万人 (1,039.2)、松江市14万人 (813.1) である(4)。本稿の分析においては、都市度を 「日常的に接触可能な人口量」(5) と「人口の集中」の両面から捉元、東京 1,186 万人 $(5,430.8)$ 、 福岡124万人 (3677.5)、新潟、富士、松江の 5 区分に序列づけた(6)。

インティメイト・ネットワークについて、質問票では、両親・子供・同居している家族 以外で最も親しい 1 人を想起してもらい属性や回答者との関係性など14項目を尋ねている (7)。最も親しい人との出会いの社会的文脈は、「親戚」、「学校時代の友人」、「現在の職場 · 仕事関係」、「子供を通じての友人」、「習いごとやサークルを通じての友人」、「近所」「て の他」から選択してもらい、さらに、「親戚」の場合には、「自分のきょうだい」、「配偶 者のきょうだい」、「おじ・おば」、「いとこ」、「おい・めい」、「その他」の中から続柄を回 答してもらった。相手との関係性の質問項目としては、知り合ってからの年数、および、 相手との居住地間時間距離を実数で、また、接触頻度、電話頻度、および、相手に対する 配偶者の認知度をカテゴリーで回答してもらった。

\section{表-1 分析対象の基本属性}

\begin{tabular}{|c|c|c|c|c|c|c|c|}
\hline & & 東京 & 福岡 & 新潟 & 富士 & 松江 \\
\hline & & (N) & 183 & 185 & 109 & 116 & 139 \\
\hline \multirow[t]{2}{*}{ 性 別 } & 男性 & 347 & 46.4 & 47.6 & 51.4 & 51.7 & 41.7 \\
\hline & 女性 & 385 & 53.6 & 52.4 & 48.6 & 48.3 & 58.3 \\
\hline \multirow[t]{4}{*}{ 年 齢 } & 30 代 & 107 & 11.5 & 21.6 & 7.3 & 19.8 & 10.8 \\
\hline & 40 代 & 199 & 26.2 & 25.9 & 26.6 & 29.3 & 28.8 \\
\hline & 50 代 & 214 & 30.1 & 26.5 & 33.9 & 31 & 26.6 \\
\hline & 60 代以上 & 212 & 32.2 & 25.9 & 32.1 & 19.8 & 33.8 \\
\hline \multirow[t]{3}{*}{ 学 歴 } & 初等 & 138 & 12 & 13.7 & 27.1 & 24.3 & 27.4 \\
\hline & 中等 & 357 & 47.4 & 50.3 & 56.1 & 45.9 & 55.6 \\
\hline & 高等 & 208 & 40.6 & 36 & 16.8 & 29.7 & 17 \\
\hline \multirow[t]{3}{*}{ 収 入 } & 500万円未満 & 201 & 23.5 & 27.3 & 34.3 & 22.1 & 34.3 \\
\hline & 500-900万円 & 295 & 36.9 & 39.9 & 39.8 & 51.3 & 40.1 \\
\hline & 900万円以上 & 224 & 39.7 & 32.8 & 25.9 & 26.5 & 25.5 \\
\hline
\end{tabular}

註）数値はパーセンテージ

註）学歴; 初等=旧制小学校、新制中学 中等＝旧制中学、新制高校

高等 $=$ 旧制高校以上、新制短大 $\cdot$ 高専以上

収入は世帯収入 


\section{3. 最も親しい人としての親族}

\section{（1）インティメイト・ネットワークの規定要因}

ここでは、どのような属性の人たちが最も親しい人との出会いの社会的文脈が親戚であ るのかについて検討する。

表一2 インティメイト・ネットワーク(親戚)に関するロジスティック回帰分析 (従属変数 $=$ 最も親しい人が親戚 $(1) /$ 違う $(0)$ )

\begin{tabular}{|c|rll|}
\hline $\mathrm{N}$ & 691 & & \\
\hline$-2 \mathrm{~L} \mathrm{~L}(0)$ & 693.8 & & \\
Model Chi & 28.9 & & $* * *$ \\
\hline & $\mathrm{b}$ & Wald & \\
性 別 & -0.07 & 0.11 & $\mathrm{~ns}$ \\
年 齢 & 0.02 & 2.83 & $\mathrm{~ns}$ \\
教育年数 & -0.11 & 6.22 & $*$ \\
世帯収入 & 0.00 & 0.30 & $\mathrm{~ns}$ \\
都 市 度 & & 10.66 & $*$ \\
東 京 & -0.84 & 8.33 & $* *$ \\
福 岡 & -0.61 & 4.87 & $*$ \\
新 潟 & -0.73 & 5.42 & $*$ \\
富 士 & -0.62 & 3.85 & $*$ \\
Constant & -0.55 & & \\
\hline
\end{tabular}

註) $* * * \mathrm{p}<.001, * * \mathrm{p}<.01, * \mathrm{p}<.05$, ns $\mathrm{p}>.05$

性別はダミー変数で、男性 $=1$ 、女性=0 とした。

都市度はダミー変数で、松江を基準カテゴリーとした。

表一 2 は、最も親しい人との出会いの社会的文脈が親戚であるかどうかを従属変数とし たロジスティック回帰分析の結果である。独立変数としては、都市度に加えて、先行研究 で示された示唆から、性別、年齢、教育年数、世帯収入を投入した(8)。従属変数について は、最も親しい人が「親戚である」を $1 、 「$ 親戚ではない」を０として分析した。その結 果、都市度と教育年数が有意な効果を示した。教育年数についてはそれが低い人ほど、最 も親しい人を親戚から選択する確率が高くなる。また、表一 2 であげた独立变数の他に職 業（従業形態）、居住歴、地域移動経験をコントロールしてもなお、教育年数の有意な効 果に変わりはなかった。教育年数は、親族ネットワークの規模にも有意な効果をもってお り、関連性の深さを示す結果となった (9)。しかし、都市度については、慎重な見方をしな ければならない。というのは、都市度が最も低い松江を基準とすると、他の 4 都市、東京、 福岡、新潟、富士は最も親しい人を親戚から選択する確率が低くなるという結果を得られ るが、福岡、新潟、富士の回帰係数が、都市度の序列にしたがってないので、単純に都市 度が低いほど、最も親しい人を親戚から選択する確率が高くなるとは言えないからである。 さらに、都市度が最も高い東京を基準とすると、松江についてのみ有意な差が見られ、福 岡、新潟、富士とは有意な差ではない(10)。したがって、最も親しい人を親戚から選択す るかどうかについての都市度の効果は有意ではあるが、限定的なものととらえなければな 
らない結果となった。

（2）インティメイト・ネットワークの諸特性

次に、最も親しい人としての親族とはどのようつき合い方をしているのかについて、検 討する。

表一 3 最も親しい人との出会いの文脈別 : 関係数

\begin{tabular}{|c|c|c|c|c|c|c|c|c|c|}
\hline & $\mathrm{N}$ & 近 親 & $\begin{array}{l}\text { 親しい } \\
\text { 親戚 }\end{array}$ & $\begin{array}{l}\text { 世帯外親 } \\
\text { 族関係 }\end{array}$ & $\begin{array}{l}\text { 学校友 } \\
\text { 人 }\end{array}$ & $\begin{array}{l}\text { 職場友 } \\
\text { 人 }\end{array}$ & $\begin{array}{l}\text { 子供友 } \\
\text { 人 }\end{array}$ & $\begin{array}{l}\text { 習い事 } \\
\text { 友人 }\end{array}$ & $\begin{array}{l}\text { 近隣友 } \\
\text { 人 }\end{array}$ \\
\hline 親 戚 & 133 & 1.98 & 1.33 & 2.07 & 1.44 & 0.71 & 0.89 & 1.05 & 0.79 \\
\hline 学 校 & 172 & 1.72 & 1.22 & 1.83 & 3.86 & 0.52 & 0.78 & 1.12 & 0.93 \\
\hline 職 場 & 136 & 1.87 & 1.22 & 1.93 & 1.37 & 1.09 & 0.44 & 1.01 & 0.77 \\
\hline 子 供 & 52 & 1.78 & 1.14 & 1.83 & 1.73 & 0.41 & 2.94 & 1.37 & 1.20 \\
\hline 習い事 & 61 & 1.92 & 1.20 & 1.99 & 1.79 & 0.40 & 0.48 & 5.13 & 1.16 \\
\hline 近 隣 & 67 & 1.95 & 1.29 & 2.03 & 1.04 & 0.56 & 0.82 & 1.46 & 1.15 \\
\hline \multirow[t]{3}{*}{ その他 } & 14 & 1.66 & 0.77 & 1.52 & 1.33 & 0.29 & 0.67 & 0.53 & 0.51 \\
\hline & 635 & 1.85 & 1.23 & 1.93 & 2.09 & 0.66 & 0.88 & 1.51 & 0.92 \\
\hline & & $* * *$ & ns & $* * *$ & $* * *$ & **** & $* * *$ & $* * *$ & $* * *$ \\
\hline
\end{tabular}

註）関係数は実数に 1 を加えて対数変換した值

註） $* * *=p<.001 \quad ; * *=p<.01 \quad ; *=p<.05$

まず、最も親しい人が親戚である人は、親族ネットワーク・サイズも大きいのかどうか について見ていくことにする(11)。表－3は、親族関係、学生時代に知り合った友人 (以下、 学校友人と呼ぶ)、職場や仕事で知り合った友人 (同、職場友人)、子どもを通じて知り合 った友人 (同、子供友人)、習い事やサークル・団体活動を通じて知り合った友人 (同、習 い事友人)、そして近所の友人 (同、近隣友人) のそれぞれの平均人数について、インテ イメイト・ネットワークの出会いの社会的文脈によって、比較したものである。

表一4 最も親しい人の文脈別ネット ワーク占める親族比率

\begin{tabular}{|c|c|c|}
\hline & $\mathrm{N}$ & $\%$ \\
\hline 親 戚 & 130 & 44.1 \\
\hline 学 校 & 169 & 31.1 \\
\hline 職 場 & 133 & 35.0 \\
\hline 子 供 & 51 & 32.8 \\
\hline 習い事 & 58 & 34.4 \\
\hline 近 隣 & 63 & 41.7 \\
\hline \multirow[t]{2}{*}{ その他 } & 14 & 32.9 \\
\hline & 618 & 36.2 \\
\hline
\end{tabular}

註） F検定 $0.01 \%$ 有意

表一 5 最も親しい人（親戚）の続柄

\begin{tabular}{|l|r|r|}
\hline & \multicolumn{1}{|c|}{$\mathrm{N}$} & \multicolumn{1}{|c|}{$\%$} \\
\hline 自分のきょうだい & 64 & 48.5 \\
配偶者のきょうだい & 22 & 16.7 \\
おじ・おば & 9 & 6.8 \\
いとこ & 23 & 17.4 \\
おい・めい & 7 & 5.3 \\
その他 & 7 & 5.3 \\
\hline & 132 & 100.0 \\
\hline
\end{tabular}

最も親しい人が親戚である人は、近親関係保有量、親しい親戚の人数、世帯外親族関係 
数がすべて最も多くなっている。したがって、最も親しい人が親戚である人は、親族ネッ トワーク・サイズ自体も大きいと言えよう。また、パーソナル・ネットワークに占める世 帯外親族関係の比率も $44.1 \%$ と最も高くなっている(表一 4 )。これらのことから、最も親 しい人が親戚である人は、他の文脈に比べて、親族関係に傾斜したつきあいを保持する傾 向にあると考元られる。他方、各友人関係数については、近隣関係を除いて、その最大数 を示す文脈はインティメイト・ネットワークの文脈と一致していた(12)。

次に、最も親しい人としての親戚の具体的な続柄を見ると、自分のきょうだいが $48.5 \%$ (64人) で最も多くなっている（表－5）。本分析では、親・子供・同居の家族は含まれて ないので、別居の自分のきょうだいが本人にとって最も近親になるが、選択的・選好的紐 帯である最も親しい人としては、この近親者が最も多い結果になった。

最も親しい人との交際頻度を示しているのが、表一6である。最も親しい人が親戚であ る場合、対面接触の回数は「月 $1 、 2$ 回」が最も多くなっている。これは、「近隣」を除い て、他の文脈と同じである。際立った特徵は、「親戚」に関してょりむしろ、「学校」の対面 接触頻度の少ない人の割合が高いことと、「習い事」および「近隣」のそれが多い人の割合が 高いことに見られる。これは回答者と最も親しい人の居住地間の時間距離にも影響を受け ていると考えられる(平均時間距離は; 「親戚」61.7分、「学校」77.7分、「職場 550.3 分、「子供」 26.7 分、「習い事 $\rfloor 31.8$ 分、「近隣」11.2分、「その他 $\rfloor 40.7$ 分、全体平均 52.1 分)。紙幅の都合 上、電話頻度のクロス集計表をここに提示することはできないが、対面接触頻度と同様の 分析を行ったところ、電話で話す回数も「月 $1 、 2$ 回」が最も多くなっている。しかし、 対面接触がほとんどない人がわずか $1.5 \%$ であるのに対して、電話で話すことがほとんど ない人が $13.6 \%$ いる点は、これら $2 つ の$ 交際手段の間の大きな相違になっている。

\section{表一 6 最も親しい人：出会いの文脈別対面接触頻度}

\begin{tabular}{|c|c|c|c|c|c|c|c|c|}
\hline & $(\mathrm{N})$ & $\begin{array}{l}\text { ほとんど } \\
\text { 毎日 }\end{array}$ & $\begin{array}{l}\text { 週 2、3 } \\
\text { 回 }\end{array}$ & 週 1 回 & $\begin{array}{l}\text { 月 } 1 、 2 \\
\text { 回 }\end{array}$ & $\begin{array}{l}2 、 3 \text { ヶ } \\
\text { 月に } 1 \text { 回 }\end{array}$ & $\begin{array}{l}\text { 年 1、2 } \\
\text { 回 }\end{array}$ & $\begin{array}{l}\text { ほとんど } \\
\text { ない }\end{array}$ \\
\hline \multirow[t]{2}{*}{ 親 戚 } & 131 & 7 & 12 & 18 & 48 & 22 & 22 & 2 \\
\hline & & $5.3 \%$ & $9.2 \%$ & $13.7 \%$ & $36.6 \%$ & $16.8 \%$ & $16.8 \%$ & $1.5 \%$ \\
\hline \multirow[t]{2}{*}{ 学 校 } & 172 & 1 & 5 & 19 & 51 & 34 & 50 & 12 \\
\hline & & $0.6 \%$ & $2.9 \%$ & $11.0 \%$ & $29.7 \%$ & $19.8 \%$ & $29.1 \%$ & $7.0 \%$ \\
\hline \multirow[t]{2}{*}{ 職 場 } & 136 & 17 & 12 & 15 & 48 & 20 & 19 & 5 \\
\hline & & $12.5 \%$ & $8.8 \%$ & $11.0 \%$ & $35.3 \%$ & $14.7 \%$ & $14.0 \%$ & $3.7 \%$ \\
\hline \multirow[t]{2}{*}{ 子 供 } & 52 & 2 & 5 & 12 & 17 & 9 & 6 & 1 \\
\hline & & $3.8 \%$ & $9.6 \%$ & $23.1 \%$ & $32.7 \%$ & $17.3 \%$ & $11.5 \%$ & $1.9 \%$ \\
\hline \multirow[t]{2}{*}{ 習い事 } & 60 & 2 & 14 & 16 & 21 & 5 & 2 & 0 \\
\hline & & $3.3 \%$ & $23.3 \%$ & $26.7 \%$ & $35.0 \%$ & $8.3 \%$ & $3.3 \%$ & $0.0 \%$ \\
\hline \multirow[t]{2}{*}{ 近 隣 } & 67 & 13 & 20 & 15 & 13 & 3 & 3 & 0 \\
\hline & & $19.4 \%$ & $29.9 \%$ & $22.4 \%$ & $19.4 \%$ & $4.5 \%$ & $4.5 \%$ & $0.0 \%$ \\
\hline \multirow[t]{4}{*}{ その他 } & 15 & 1 & 3 & 3 & 4 & 2 & 0 & 2 \\
\hline & & $6.7 \%$ & $20.0 \%$ & $20.0 \%$ & $26.7 \%$ & $13.3 \%$ & $0.0 \%$ & $13.3 \%$ \\
\hline & 633 & 43 & 71 & 98 & 202 & 95 & 102 & 22 \\
\hline & & $6.8 \%$ & $11.2 \%$ & $15.5 \%$ & $31.9 \%$ & $15.0 \%$ & $16.1 \%$ & $3.5 \%$ \\
\hline
\end{tabular}

註）カイ二乗検定 $0.1 \%$ 有意 
表一 7 最も親しい人 : 出会いの文脈別配偶者認知

\begin{tabular}{|l|r|r|r|r|r|}
\hline & $(\mathrm{N})$ & $\begin{array}{l}\text { 親しいつ } \\
\text { きあい }\end{array}$ & $\begin{array}{l}\text { 会ったこ } \\
\text { とはある }\end{array}$ & $\begin{array}{l}\text { 話には聞 } \\
\text { いている }\end{array}$ & $\begin{array}{l}\text { 全く知ら } \\
\text { ない }\end{array}$ \\
\hline 親 戚 & 131 & 119 & 9 & 2 & 1 \\
& & $90.8 \%$ & $6.9 \%$ & $1.5 \%$ & $0.8 \%$ \\
\hline 学 校 & 171 & 90 & 64 & 13 & 4 \\
& & $52.6 \%$ & $37.4 \%$ & $7.6 \%$ & $2.3 \%$ \\
\hline 職 場 & 136 & 57 & 52 & 19 & 8 \\
& & $41.9 \%$ & $38.2 \%$ & $14.0 \%$ & $5.9 \%$ \\
\hline 子 供 & 51 & 18 & 28 & 4 & 1 \\
& & $35.3 \%$ & $54.9 \%$ & $7.8 \%$ & $2.0 \%$ \\
\hline 習い事 & 59 & 26 & 24 & 7 & 2 \\
& & $44.1 \%$ & $40.7 \%$ & $11.9 \%$ & $3.4 \%$ \\
\hline 近 隣 & 67 & 49 & 18 & 0 & 0 \\
& & $73.1 \%$ & $26.9 \%$ & $0.0 \%$ & $0.0 \%$ \\
\hline その他 & 15 & 9 & 4 & 2 & 0 \\
& & $60.0 \%$ & $26.7 \%$ & $13.3 \%$ & $0.0 \%$ \\
\hline \hline & 630 & 368 & 199 & 47 & 16 \\
& & $58.4 \%$ & $31.6 \%$ & $7.5 \%$ & $2.5 \%$ \\
\hline
\end{tabular}

註）カイ二乗検定 $0.1 \%$ 有意

最も親しい人との交際の仕方について、配偶者がどのようなスタンスをとっているかを 示したのが表ー 7 である。最も親しい人が親戚である場合の最も顕著な特徵は、「配偶者 も親しくつきあっている」と回答した比率が約 $90 \%$ と圧倒的に高いことである。この結果 からは、最も親しい人が親戚である人は相手と夫婦ぐるみで交際していることがわかる。

\section{4. 結語}

最後に、考察とまとめを行うことによって本稿の結語としたい。本稿では、親族ネット ワークの特性を明らかにするために、インティメイト・ネットワークに着目して分析を行 ってきた。どのような人が最も親しい人を親戚から選択するかに関して、ただ単に属性ご との比率を見るだけでなく、他の変数をコントロールしたうえでの分析は、残念ながらこ れまでほとんど行われてこなかった。その意味で、今回の分析は、親族ネットワークの特 性について、一つの知見を提供できたのではないかと思われる。

分析結果について見ると、まず、最も親しい人を親戚から選択する要因として、教育年 数と都市度が有意な効果をもつことが明らかになった。教育年数は、他のどの変数の影響 をコントロールしても、その効果が残ることから、独立変数としての強さが確認されたと 言える。教育年数が長い、すなわち、高学歴者は、低学歴者に比べて、学校時代の友人が 多い。学校が関係形成の場であり、高学歴者はその学校の在籍期間が長いからである。さ らに、学校時代の友人とは、全人格的につきあった歴史があるうえに、その後も利害関係 なしにつきあえるので、単なる友人以上の最も親しい人となる可能性が高くなることは容 
易に想像できるだろう。そのような最も親しい人の「貯水池」(Fischer 1984=1996：194） をもたない低学歴者は、最も親しい人の「貯水池」として親戚に向かう確率が高くなるの ではないかと考えられる。他方、都市度の効果が、限定的なものとはいえ、最も親しい人 を親戚から選択する要因として見出されたことは、都市度が親族関係の選択性に一定の影 響をもっていることを明らかにした。都市度が低いところでは、最も親しい人を友人の 「貯水池」から引き出せないことが、親戚に求める結果につながったと予想される。しか し、都市度の高い東京、福岡、新潟、富士の間では、都市度の差異ほど友人の「貯水池」 の差異は大きくない、つまり、都市度が高いからといって、現実につきあう友人の数が多 くなることはないのであり(13)、都市度の差異は「友人選択に際していくらか選択の幅が 大きく」（Fischer 1984=1996：194）なる程度の差異しか生まないため、結果的に、最も 親しい人を親戚から選択する可能性もまた広がらなかったのではないだろうか。

次に、最も親しい人としての親戚とのつきあいの様相について見ると、接触頻度につい ては、きわだって顕著な特徵は見出されなかったものの、配偶者のスタンスの取り方が、 他の出会いの社会的文脈と大きな差異があり、その親戚とは、配偶者とも親しい親戚とし てのつきあいがあり、夫婦ぐるみでの交際をしている割合が高いことが明らかになった。

都市住民の親族ネットワークについて分析、考察を行った結果、上記のような知見が得 られたわけであるが、都市という独立変数がその都市に居住する人たちの親族ネットワー クへ与える効果に関する検証は、たとえば、本稿で取り上げた以外の都市を対象にするな どして、さらに積み重ねていく必要があるだろう。また、インテイメイト・ネットワーク という切り口は、まだ研究の蓄積が少ない分、今後さらに改良、発展の可能性を秘めてい るように思われる。したがって、親族ネットワークだけでなく、友人関係や近隣関係、職 場関係など、個人がとり結ぶ多様な社会関係への適用を試みることも今後の課題となろ う。

註

（1）たとえば、野辺のキャンベラでの調査（野辺 1991）、野沢の墨田区における職業的地位とパーソ ナル・ネットワークの研究がある（野沢 1992）。

(2) 林は、個人の属性として職業的地位に着目して、対象者本人とインティメイト・ネットワークの相 手の職業的地位とどの程度関連があるかを分析し、その同類結合について明らかにしている（林 1997)。

（3）本調査は、平成 6 年度～平成 8 年度科学研究費補助金（基盤研究（A）-（1））：研究代表者森岡 清志「都市度とパーソナルネットワークに関する研究」による。

(4) 1990年国勢調査による。

（5）松本は、「パーソナル・ネットワークの観点からは、アーバニズム（都市度）は、「ある場所におけ る、日常的に接触可能な人口量」とするのが、論理的に最も首尾一貫しており、発展可能性が高い。」 と主張している（松本 1995：87）。本稿で採用した都市度の定義もこれに依拠している。

(6) 東京、福岡の人口と人口密度は、それぞれ、東京都、および、福岡市のものである。

（7）最も親しい人についての質問項目は；性別、年齢、居住地間時間距離、対面接触頻度、電話で話す 回数、出会いの社会的文脈、つきあいの年数、配偶者の有無、出身地、最終学歴、現在就いている職 業の形態・企業規模・職種、配偶者の認知度である。

（8）大谷は、性別、年齢（カテゴリー）、学歴（カテゴリー）、収入（カテゴリー）、「結婚状況」のそれ ぞれについて、「最も親しい人の種類」（親戚・近所・友人・職場）の比率を検討している（大谷 前 掲書：125-127)。本分析では、先行研究の成果をさらに精緻化するために、他の变数の影響を除去し 
ても残る独立変数の効果を測定できる方法をとった。投入した变数のうち、教育年数は、質問票では 最終学歴をカテゴリーで質問しているのを次のように変換したものである; 旧制小学校 $=7$ 年、旧制 中学校 $=11$ 年、旧制高校 $=14$ 年、旧制大学 $=17$ 年、新制中学校 $=9$ 年、新制高校 $=12$ 年、新制短大 高専 $=14$ 年、新制大学 $=16$ 年、医学部・大学院 $=18$ 年。また、世帯収入もカテゴリーで質問されてい るので、各カテゴリーの中央值から、「300万円未満」=300万円、「300万～500万円未満」 $=400$ 万円、 「500万～700万円未満」＝600万円、「700万～900万円未満」＝800万円、「900万～1100万円未満」= 1000万円、「1100万～1300万円未満」＝1200万円、「1300万～1500万円未満」＝1400万円、「1500万円 以上」 $=1500$ 万円という量的変数に变換した。

（9）親族ネットワークの規模に関して、近親関係保有量、親しい親戚の人数、世帯外親族関係数を従属 変数として分散分析を行ったところ、次のような結果になった。近親関係保有量に対しては、都市度、 年齢、教育年数が有意な効果をもっていたが、性別、居住歴（ 5 年未満・5 20年・20年以上という カテゴリー)、地域移動経験（非移動・近距離移動・遠距離移動というカテゴリー）、世帯収入（500 万円未満、500万～900万円未満、900万円以上というカテゴリー）は有意な効果をもたなかった。親 しい親戚の人数に対しては、性別と教育年数が有意な効果をもち、都市度、居住歴、地域移動経験、 世帯収入、年齢は有意な効果をもたなかった。そして、世帯外親族関係数に対しては、都市度、居住 歴、年齢、教育年数が有意な効果をもっていたが、性別、地域移動経験、世帯収入は有意な効果をも たなかった。なお、親しい親戚の人数（両親・子供・きょうだい以外）、それらをあわせた世帯外親 族関係数を分析の対象とする。親しい親戚（の人数は、質問票では、「いない」、「1〜3人」、「4〜 6 人」、「7～9人」、「10人以上」のカテゴリー質問であるのを、それぞれの中央值をとって、0、2、 $5 、 8 、 10$ という量的変数に変換した。 親族ネットワークの各变数はその分布に偏りが見られるの で、分析の際には実数に1を加えて対数変換した数值を用いた。

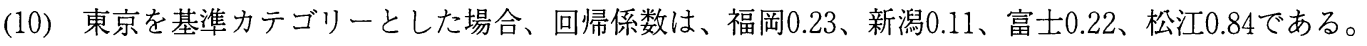

(11) 非親族ネットワークに関しては、質問票では、まず最初に友人の総数を質問し、その後、距離別、 および、出会いの社会的文脈別にその内訳の人数を質問した。非親族ネットワークの各变数はその分 布に偏りが見られるので、分析の際には実数に1を加えて対数变換した数值を用いた。

(12) この結果は、先行研究における、インティメイト・ネットワークと関係カテゴリーごとのネットワ ーク・サイズとの関連についての指摘を再確認したことになった（大谷 1995:105-106）。ただし、 大谷の四国調査と中四国調査においては、出会いの社会的文脈として「子供を通じて」と「習い事や サークル・団体活動を通じて」を区別してないので、近隣関係についても、関係カテゴリーごとのネ ットワーク・サイズは最大値を示している。

(13) 友人総数の都市別の平均の比較を行ったところ、有意な差はなかった。

\section{文献}

Fischer, C.S. 1982 To Dwell among Friends: Personal Network in Town and City. Univ. of Chicago Press

Fischer,C.S. 1984 The Urban Experience, 2nd ed. 松本康 - 前田尚子（訳）『都市的体験一都市生活 の社会心理学』未来社 1996

林 拓也 1997 「職業的地位とネットワーク特性」『総合都市研究』64、東京都立大学都市研究所、 pp. $25-38$

松本康 1995 「現代都市の変容とコミュニティ、ネットワーク」『増殖するネットワーク』、勁草書 房、pp.1-90

野辺政雄 1991 「コミュニティ・クエスチョン-キャンベラにおける検証-」『社会学評論』42（2） pp.2-17

野沢慎司 1992 「インナーエリアとコミュニティの変容」『大都市社会のリストラクチュアリング』 日本評論社 pp.125-152

大谷信介 1995 『現代都市住民のパーソナルネットワーク』ミネルヴァ書房

大橋薰・清水新二 1972 「都市における親族関係の一考察川崎市 S小学校区の場合」『明治学院論叢』 195 pp.1-34 (『リーディングス日本の社会学 4 『現代家族』所収） 1987 東京大学出版会 
Simmel,G 1903 Die Grossstäte und das Geistesleben=1965 松本通晴（訳）「大都市と心的生活」、鈴木 広 (編)『都市化の社会学』 誠信書房

Wellman,B 1979 The Community Question: The Intimate Networks of East Yokers AJS 84 (5) pp.12011231

安河内恵子 1995 「都市社会における集団参加とネットワーク形成」『都市問題』86（9） pp.27-40 東京市政調查会

(東京都立大学大学院社会科学研究科博士課程) 